\title{
Tinjauan Yuridis Pemberian Remisi Kepada Narapidana Tindak Pidana Korupsi Ditinjau dari Tujuan Pemidanaan (Studi Kasus di Lembaga Pemasyarakatan Kelas II - A Kota Bengkulu)
}

\author{
Juridical Review of Remission to Prisoners of Corruption Crime \\ Viewed from Criminal Objectives \\ (Case Study in Class II - A Penitentiary of Bengkulu City)
}

\section{Imam Hafizta Winanda}

Universitas Muhammadiyah Bengkulu, email: imam.hafistawinanda@gmail.com

\begin{abstract}
ABSTRAK
Tindak pidana korupsi yang terjadi di Indonesia sejatinya telah meluas dalam kehidupan masyarakat. Penjatuhan sanksi pidana penjara oleh hakim tindak pidana korupsi tidak membuat orang takut melakukan korupsi. Bahkan dengan adanya pemberian remisi bagi narapidana tindak pidana korupsi sangat bertentangan dengan tujuan pemidanaan itu sendiri efek jera dan pembinaan. Permasalahan dalam artikel ini dapat dirumuskan sebagai berikut 1) apakah tujuan pemberian remisi kepada narapidana tindak pidana korupsi 2) apakah pemberian remisi terhadap narapidana tindak pidana korupsi. Dari hasil penelitian di Lembaga Pemasyarakatan Kelas II - A Kota Bengkulu tujuan utama pemberian remisi adalah sebagai motivasi agar narapidana tindak pidana korupsi tidak lagi mengulangi perbuatannya tetapi remisi disini bukan untuk mendorong mereka untuk merubah akhlak mereka tetapi cenderung berpura - pura baik untuk cepat keluar dari lembaga pemasyarakatan, faktanya dalam hal ini jelas pemberian remisi sungguh tidak sesuai dengan semangat Pemerintah untuk memberantas tindak pidana korupsi dan tidak sesuai dengan tujuan dari pemidanaan karena dengan pemberian remisi justru tidak menimbulkan kejeraan bagi pelaku tindak pidana korupsi. Bentuk hukum responsif untuk kesejahteraan masyarakat tidak bisa tercapai.
\end{abstract}

\section{Kata kunci : Pemberian Remisi, Tujuan Pemidanaan}

\begin{abstract}
The criminal act of corruption that occurred in Indonesia has actually been widespread in people's lives. The imposition of imprisoned criminal sanctions by a corruption criminal act judge does not make people afraid of doing corruption. Even with the provision of remissions for inmates of the corruption criminal act is very contrary to the purpose of punishment itself such as the deterrent effect and guidance. The problems in this study can be formulated as follows: 1) what is the purpose of giving remission to the criminal
\end{abstract}


Tinjauan Yuridis Pemberian Remisi Kepada Narapidana Tindak Pidana Korupsi

Ditinjau dari Tujuan Pemidanaan

inmates of corruption 2) what remission is given to the prisoners of corruption. From the results of research in Class II - A Penitentiary of Bengkulu, the main purpose of remission is as a motivation for corruption criminals not to redo their actions any longer. The remission here is not to encourage them to change their morals but tend to pretend to be good in order that they can get out quickly from the penitentiary, in fact it is clear that remission is not in line with the Government's spirit to eradicate corruption and not in accordance with the objective of criminal punishment because with the provision of remission it does not cause does not provide a deterrent effect to the corruptors. The form of responsive law for the society welfare can not be achieved.

\section{Keywords: Remission, Crime Objection}

\section{PENDAHULUAN}

Tindak pidana korupsi yang terjadi di Indonesia sejatinya telah meluas dalam kehidupan masyarakat. Seiring berjalannya waktu perkembangannya terus meningkat dari tahun ketahun, mulai dari pejabat tinggi hingga rukun tetangga. Pada kasus yang terjadi di Indonesia jenis kasus korupsi dalam bentuk kecil dalam bentuk uang sumbangan sukarela atau uang pelicin dalam pengurusan seperti Kartu Tanda Penduduk (KTP), Akta Kelahiran, Pembuatan Surat Izin Mengemudi (SIM), Surat kelakuan baik (SKB) dan lain sebagainya.

Itu sebabnya muncul paham bahwa korupsi di Indonesia sudah menjadi pola hidup sebagian masyarakat, karena terjadi hampir di semua sektor dan lapisan masyarakat. Meningkatnya tindak pidana korupsi yang tidak terkendali akan membawa bencana, terhadap kehidupan perekonomian nasional prilaku koruptif elit politik dan kehidupan berbangsa dan bernegara pada umumnya. semakin membuat parah kemiskinan yang sudah sangat parah dan sangat sulit di atasi.

Meskipun telah diundangkannya peraturan-peraturan yang diupayakan pemerintah untuk memberantas atau setidaknya mengurangi membudayanya korupsi tersebut, akan tetapi belum dapat membuat tindak pidana korupsi di Indonesia hilang. Berbagai wacana untuk menurunkan praktek korupsi di Indonesia pun telah dicanangkan, diantaranya yaitu tentang merevisi Peraturan Perundangundangan tentang pemberian remisi atau pengurangan masa pidana terhadap pelaku tindak pidana korupsi dan bahkan ada wacana untuk menghapus remisi terhadap para narapidana korupsi tersebut. Masyarakat banyak yang mempertanyakan kebijakan Kementerian 
P-ISSN : 2599-1892

Vol. 1, No. 1, Januari 2018

Hukum dan HAM yang dalam hal ini sebagai pelaksana pemberian remisi terhadap koruptor yang sebelumnya di usulkan terlebih dahulu oleh Kalapas. Di lapas kelas II - A Kota Bengkulu sendiri tahun 2014 setidaknya pada tahun 2015 ada 14 Narapidana tindak pidana korupsi yang diusulkan pihak lapas kepada Kementrian Hukum dan Ham untuk mendapatkan remisi dari total keseluruhan ada 96 Narapidana yang tersangkut kasus korupsi hingga akhir maret 2015. Tidak bisa dipungkiri pemberian remisi terhadap narapidana tindak pidana korupsi di Lembaga Pemasyarakatan Kelas II - A Kota Bengkulu sendiri mengikuti prosedur dari Undang - Undang Nomor 12 tahun 1995 tentang pemasyarakatan, yang remisi merupakan hak dari narapidana manapun. Dari latar belakang diatas, maka dapat diuraikan permasalahan yaitu sebagai berikut :

1. Apakah tujuan pemberian remisi kepada narapidana tindak pidana korupsi pada warga binaan lembaga pemasyarakatan kelas - II A Kota Bengkulu ?

2. Apakah pemberian remisi terhadap narapidana tindak pidana korupsi pada warga binaan lembaga pemasyarakatan kelas II - A Kota
Bengkulu telah sejalan dengan tujuan pemidanaan ?

\section{METODE PENELITIAN}

Sesuai dengan perumusan masalah yang telah dikemukakan penulis maka penelitian ini empiris. Penelitian dengan pendekatan empiris adalah sebagai usaha mendekati masalah yang akan diteliti dengan sifat hukum yang nyata atau sesuai dengan kenyataan hidup yang ada didalam masyarakat. ${ }^{1}$

Dalam penelitian hukum data - data yang dikumpulkan itu merupakan data primer dan data sekunder, yaitu :

1. Data Primer

Data primer, data yang diperoleh melalui penelitian lapangan dengan cara wawancara , dimana dalam melakukan wawancara tersebut menggunakan pedoman wawancara yang telah dipersiapkan sebelumnya dan dengan cara tanya jawab. ${ }^{2}$ Dimana penulis akan mengendalikan sendiri pertanyaan - pertanyaan yang akan diajukan pada saat wawancara berlangsung. Hal ini dimaksudkan supaya informan dapat dengan leluasa mengungkapkan fakta yang ada.

${ }^{1}$ Hilman Hadikusuma, Metode Penulisan Kertas Kerja dan Pembuatan Skripsi, Bandung, Rosda Karya; 1995, HIm.61

${ }^{2}$ Ibid 
Tinjauan Yuridis Pemberian Remisi Kepada Narapidana Tindak Pidana Korupsi

Ditinjau dari Tujuan Pemidanaan

2. Data Sekunder

Data - data yang diperoleh melalui kepustakaan dan dokumentasi yang merupakan hasil penelitian dan pengolahan orang lain. Data sekunder dibidang hukum dibagi menjadi 3 bagian yaitu :

a. Bahan Hukum Primer

Data yang mempunyai kekuatan hukum yang mengikat, data diperoleh dari :

- Al Quran dan Al Hadits.

- Undang - undang Dasar Negara Republik Indonesia 1945.

- Undang - undang Republik Indonesia No. 31 tahun 1999 tentang pemberantasan tindak pidana korupsi.

- Peraturan Pemerintah No. 99 tahun 2012 tentang Perubahan kedua atas Peraturan Pemerintah No.32 tahun 1999 tentang syarat dan tata cara pelaksanaan hak warga binaan pemasyarakatan.

- Undang - undang No. 12 tahun 1995 tentang Pemasyarakatan

- Undang - undang No. 8 tahun 1981 tentang Kitab Undang undang Hukum acara Pidana.

- Undang - undang No.30 tahun 2002 tentang Komisi pemberantasan tindak Pidana Korupsi.

- Undang - undang No. 46 tahun 2009 tentang Pengadilan Tindak Pidana Korupsi.

- Undang - undang No.71 tahun 2001 tentang Tata Cara pelaksanaan peran serta masyarakat dan pemberian penghargaan dalam pencegahan dan pemberantasan korupsi.

- Undang - undang No.28 tahun 1999 tentang Penyelenggara Negara yang bersih dan bebas dari Korupsi, Kolusi dan Nepotisme.

- Undang - undang No.12 tahun 1995 tentang Lembaga Pemasyarakatan.

b. Bahan Hukum Sekunder Merupakan bahan-bahan yang erat hubungannya dengan bahan hukum primer dan dapat membantu serta menganalisis data penelitian yang akan dilakukan. Bahan Hukum Primer diperoleh melalui :

- Rancangan Undang - undang.

- Buku - buku para sarjana

- Hasil Penelitian

- Jurnal

- Makalah

- Dan lain sebagainya 
c. Bahan Hukum Tersier

Yaitu bahan - bahan yang memberikan informasi tentang bahan hukum primer dan bahan hukum sekunder. Data diperoleh dari

- Koran, Kliping, Artikel, Internet, dan lain sebagainya.

\section{Studi Lapangan}

Studi lapangan yang dimaksud penulis adalah upaya untuk memperoleh data - data langsung berupa dokumentasi dari instansi pemerintah yang berwenang dan terkait dengan, penegakan hukum pidana. Hal ini dilakukan penulis dikarenakan kemungkinan besar tidak semua data - data yang diperlukan dapat diperoleh atau tersedia dalam bentuk sumber tulisan (Kepustakaan), dalam hal ini dapat dilakukan dengan cara wawancara dengan aparatur negara, para ahli hukum, ataupun praktisi hukum yang terkait dengan pokok permasalahan yang diangkat.

Alat ukur yang digunakan oleh penulis adalah wawancara berupa daftar pertanyaan yang berbentuk suatu schedule atau suatu kuisioner, yang biasanya telah terstruktur ${ }^{3}$. Jadi penulis menggunakan wawancara langsung untuk memperoleh data sekaligus juga pengumpulan data tertulis lainnya yang bisa didapat dari narasumber (responden).

\section{Studi Kepustakaan}

Studi kepustakaan adalah hal yang paling penting dimana seorang peneliti telah menemukan objek yang akan diteliti, langkah selanjutnya adalah melakukan kajian - kajian yang berkaitan dengan teori yang berkaitan dengan objek penelitian. Dalam hal ini pencarian teori, peneliti akan mengumpulkan informasi yang sebanyak - banyaknya dari kepustakaan yang berkaitan. Sumber sumbernya sendiri bisa diperoleh dari Buku, Jurnal, Majalah, hasil penelitian (tesis dan disertasi), dan sumber sumber lainnya yang sesuai (internet,Koran,dll). Bahan - bahan pustaka yang diperoleh dalam bentuk soft copy biasanya dapat diperoleh dari sumber - sumber di internet yang dapat diperoleh secara online.

Dengan begitu penelitian ini akan mudah dilakukan dalam rentang waktu yang singkat, karena data yang dapat digunakan mudah didapat oleh peneliti. Dan hal yang paling penting haruslah mencantumkan sumber - sumber yang didapat dalam bentuk referensi. 
Tinjauan Yuridis Pemberian Remisi Kepada Narapidana Tindak Pidana Korupsi

Ditinjau dari Tujuan Pemidanaan

Analisis data yang diperlukan dalam penelitian penulis adalah analisis data deskriptif kualitatif, yaitu upaya yang dilakukan dengan jalan bekerja dengan data, mengorganisasikan data, memilahmilahnya menjadi satuan yang dapat dikelola, mensintesiskannya, mencari dan menemukan pola, menemukan apa yang penting dan apa yang dipelajari dan memutuskan apa yang dapat diceritakan kepada orang lain. ${ }^{4}$

Dalam penelitian kualitatif, sumber data dapat diperoleh berupa orang, peristiwa, lokasi, benda, dokumen, atau arsip. Beragam sumber tersebut menuntut cara tertentu yang sesuai guna mendapatkan data. Pada penelitian kualitatif proses analisnya dilakukan sejak awal bersamaan dengan proses pengumpulan data. Bahwa dengan ini hendaklah penulis dalam menganalisis data secara teliti agar mendapatkan pembahasan yang menarik.

\section{PEMBAHASAN}

\section{Tujuan Pemberian Remisi Kepada} Narapidana Tindak Pidana Korupsi Pada Warga Binaan Lembaga Pemasyarakatan Kelas II - A Kota Bengkulu.

\footnotetext{
${ }^{4}$ https://bersukacitalah.wordpress.com/ta g/tahap-tahap-analisis-kualitatif/, diakses pada tanggal 7 februari pada pukul 18.04 WIB
}

Menurut Kepala Lembaga Pemasyarakatan Kelas II - A Kota Bengkulu, mengatakan :

" Dalam sistem Pemasyarakatan Remisi merupakan hak Narapidana yang diatur berdasarkan Pasal 14 Undang Undang Nomor 12 Tahun 1995 tentang Pemasyarakatan. Berdasarkan filosofis pemasyarakatan merupakan inti dari pelaksanaan pembinaan pelanggaran hukum bertumpu pada Community Base Oriented (pelaksana pembinaan di tengah - tengah masyarakat). Oleh karena itu Remisi merupakan manifestasi dari tujuan Pemasyarakatan dimaksud. Dalam konteks ini pemberian remisi bagi narapidana yang memenuhi syarat merupakan salah satu alternatif dalam rangka mempercepat proses reintegrasi, Remisi merupakan salah satu bagian dari fasilitas pembinaan yang tidak bisa dipisahkan dari fasilitas pembinaan yang lainnya, dimana hakekat pembinaan adalah selain memberikan sanksi yang bersifat punitive, juga memberikan reward sebagai salah satu dari upaya pembinaan, agar program pembinaan dapat berjalan dan direspon oleh Warga Binaan Pemasyarakatan ". ${ }^{5}$

sedangkan tujuan dari Sistem Pemasyarakatan adalah mengupayakan

${ }^{5}$ FA. Widyo Putranto,Bc.Ip, Kepala Lembaga Pemasyarakatan Kelas II - A Kota Bengkulu (wawancara tanggal 9 mei 2015) 
warga binaan untuk tidak mengulangi lagi perbuatannya melanggar hukum yang pernah dilakukan dengan harapan kelak akan kembali dan diterima oleh masyarakat sekitarnya sebagai warga masyarakat serta dapat berperan aktif sebagaimana anggota masyarakat lainnya. Jadi dengan adanya pemberian remisi diharapkan dapat menjadi pemicu sekaligus sebagai motivator bagi para warga Binaan Pemasyarakatan yang masih menjalani pembinaan di dalam Lembaga Pemasyarakatan dan merupakan salah satu fasilitas pembinaan yang diberi kepada warga binaan pemasyarakatan dalam rangka mencapai tujuan pemasyarakatan.

\section{Apakah pemberian remisi terhadap} narapidana tindak pidana korupsi pada waga binaan lembaga pemasyarakatan kelas II - A Kota Bengkulu telah sejalan dengan tujuan pemidanaan.

Di Lembaga Pemasyarakatan seringkali kita mendengarkan bahwa narapidana mendapatkan pemotongan masa tahanan yang kita kenal dengan remisi. Setiap tahunnya remisi yang diberikan oleh kalapas setidaknya ada 5 (Lima) kali dalam satu tahun, yaitu pada saat Hari Kemerdekaan 17 Agustus
(Remisi Umum), Hari Raya Idul Fitri, Hari Raya Natal, Hari kesehatan bagi yang telah divonis mempunyai penyakit yang berat akan mendapatkan remisi, Hari anak bagi narapidana anak, dan Remisi Lansia pada hari Lansia itu untuk narapidana yang berusia diatas 70 tahun (Remisi Khusus). Hal seperti ini dibenarkan oleh Pejabat Lembaga Pemasyarakatan Kelas II - A Kota Bengkulu yang mengatakan:

" Pemberian remisi pada narapidana tindak pidana korupsi khususnya di lembaga pemasyarakatan kelas II - A Kota Bengkulu mengikuti prosedur yang telah ditetapkan pada Undang - Undang Nomor 12 tahun 1995 tentang Pemasyarakatan, jika narapidana telah memenuhi syarat - syarat pemberian remisi maka narapidana itu sendiri berhak untuk mendapatkan pemotongan masa tahanan, karena remisi itu merupakan hak narapidana". 6

Hal senada juga dikatakan oleh pejabat lembaga pemasyarakatan lainnya " Bahwa pemberian remisi dikalangan para narapidana itu adalah hak mereka, dan itu merupakan perintah dari undang - undang yang telah mengatur, kalapas hanya menjalankan perintah dari

${ }^{6}$ Sri Harmowo,BC.Ip,S.H., Kasi Binadik Lapas kelas II - A Kota Bengkulu, (wawancara tanggal 6 Mei 2015) 
Tinjauan Yuridis Pemberian Remisi Kepada Narapidana Tindak Pidana Korupsi

Ditinjau dari Tujuan Pemidanaan

kementrian hukum dan ham untuk mengusulkan siapa saja narapidana tindak pidana korupsi yang berhak mendapatkan remisi, dan selanjutnya usulan tersebut ditindaklanjuti oleh menteri hukum dan ham, apakah usulan tersebut diterima atau tidak itu kembali menjadi pertimbangan menteri hukum dan ham". ${ }^{7}$

Di lain pihak dikatakan Kepala Divisi Pemasyarakatan Kanwil Kemenkumham Bengkulu :

"Bahwa pemberian remisi terhadap narapidana sebuah tuntutan undang undang yang harus dipenuhi, kita jangan selalu terfokus kepada pelaku yang melakukan tindak pidana korupsi itu saja tetapi juga kita harus melihat sisi lainnya kenapa mereka sampai melakukan tindak pidana korupsi tersebut, kita juga harus melihat konsep pemberian remisi itu sendiri tujuannya untuk mendekatkan mereka kepada kebaikan, re-integrasinya yang disini kita pandang. ${ }^{\prime \prime}$

Dari hasil wawancara yang telah dipaparkan di atas, dapat disimpulkan bahwa Lembaga Pemasyarakatan Kelas II - A Kota Bengkulu hanya menjalankan prosedur tentang pemberian remisi terhadap narapidana yang ada di

${ }^{7}$ Samsi,BC.Ip.,S.H, Kaur Lapas Kelas II A Kota Bengkulu, (wawancara tanggal 6 Mei 2015)

8 Sunar Agus,BC.Ip,S.H.,M.H, Kadivpas Kanwil Kemenkumham Bengkulu (wawancara tanggal 6 Mei 2015)
Lembaga Pemasyarakatan Kelas II - A Kota Bengkulu menurut Undang - undang No.12 Tahun 1995 tentang Pemasyarakatan dan ditambah dengan Peraturan Pemerintah Nomor 99 tahun 2013 perubahan kedua atas Peraturan Pemerintah Nomor 32 Tahun 1999 tentang Syarat dan Tata Cara Pelaksanaan Hak Warga Binaan Pemasyarakatan.

Pemberian remisi seperti ini tentu saja tidak sesuai dengan tujuan dari pemidanaan, selama ini hukum masih menggunakan hukum represif, Philippe Nonet dan Phillip Selznick mengatakan bahwa hukum lebih mementingkan kekuasaan dari pada kesejahteraan, kekuasaan dilaksanakan tidak untuk kepentingan mereka yang diperintah, atau dengan mengingkari legitimasi mereka, setiap tindakan yang dilakukan atau keputusan yang dibuat pemerintah, mensyaratkan ditempatkannya beberapa kepentingan dibawah kepentingan lainnya dengan mengesampingkan kepentingan kepentingan dan kesejahteraan masyarakat. Sehingga narapidana tindak pidana korupsi sendiri tidak mendapatkan efek jera atas hukuman yang dihadapinya.

Pemberian remisi bagi terpidana korupsi sangat bertentangan dengan semangat pemerintah untuk memberantas tindak pidana korupsi. Ditinjau dari aspek 
teoritis, berdasarkan teori absolut pemidanaan bahwa pidana dijatuhkan sebagai ganjaran yang diberikan untuk menghukum bagi pelaku kejahatan sebagai bentuk keadilan. Hal ini sejalan dengan tujuan Negara kita yang tercantum dalam Pembukaan UUD NKRI Tahun 1945 alinea kedua yang disana dikatakan mengantarkan rakyat Indonesia ke depan pintu gerbang kemerdekaan negara Indonesia, yang merdeka, bersatu, berdaulat, adil, dan makmur. Artinya, jelas bahwa bagi pelaku kejahatan harusnya mendapatkan hukuman sebagai bentuk ganjaran yang setimpal atas perbuatannya dan Pemerintah dituntut untuk adil akan hal itu sebagaimana kita tahu bahwa masyarakat Indonesia menghendakinya apalagi tindak pidana korupsi. Selanjutnya, bagaimana masyarakat Indonesia mau makmur kalau tindak pidana korupsi masih saja terus berkembang, bahwa esensinya mereka adalah musuh terbesar rakyat Indonesia yang mencuri uang rakyat hanya untuk kepentingan pribadi atau golongan saja.

Dan ketika pemberian remisi tetap diberikan kepada terpidana korupsi maka sejatinya akan menciderai esensi tujuan pemidanaan itu sendiri serta merampas rasa keadilan bagi masyarakat Indonesia. Sejalan dengan apa yang dikatakan oleh
Johanes Andenaes bahwa tujuan primer dari pidana itu sendiri menurut teori absolut ialah untuk memuaskan tuntutan keadilan.

Pemberian remisi itu sendiri menimbulkan banyak kontroversi yang ada di tengah masyarakat, masyarakat luas pada umumnya bertanya kepada pemerintah yang memberikan remisi mengapa para koruptor yang telah membuat negara mengalami kerugian tetapi tetap mendapatkan pemotongan masa tahanan. Para narapidana yang berada di Lembaga Pemasyarakatan Kelas II - A Kota Bengkulu selain narapidana tindak pidana korupsi mengatakan :

"Ketidakadilan yang kami rasakan disini sangatlah jelas, dimana yang hanya mempunyai uang lebih bisa mendapatkan pemotongan tahanan lebih banyak, sedangkan kami hanya sebagian kecil yang mendapatkan remisi. Seperti saya sendiri menjadi narapidana dikarenakan saya melakukan pelangaran hukum seperti pencurian hanya mendapatkan remisi pertahun hanya 15 hari, itu pun jarang kami dapatkan. Kerugian yang orang lain alami dari pada kami tidaklah sebanding dengan apa yang negara alami, tetapi mengapa mereka lebih besar 
Tinjauan Yuridis Pemberian Remisi Kepada Narapidana Tindak Pidana Korupsi

Ditinjau dari Tujuan Pemidanaan

mendapatkan pemotongan masa tahan daripada kami. ${ }^{\prime \prime}$

Hal seperti yang telah dipaparkan di atas tidak memungkinkan bahwa para koruptor tersebut tidak akan mengulangi perbuatannya lagi, pelaku tindak pidana korupsi harus ada pembalasan yang berupa pidana. Jadi seseorang yang tersangkut kasus korupsi atau yang telah menjadi narapidana tindak pidana korupsi mutlak harus mendapatkan pidana sesuai dengan wewenang yang telah disalahgunakannya sebagai pejabat pemerintah dan berhitung juga tentang berapa besar kerugian negara itu sendiri.

Disisi lain Kadivpas Kanwil Kemenkumham Bengkulu mengatakan :

" Jika pemberian remisi tidak menimbulkan kejeraan bagi narapidana dan narapidana tidak menjadi baik setelah keluar dari Lapas, berarti sistem pembinaan di Lembaga Pemasyarakatan yang salah, berarti kita harus membenarkan konsep pembinaan warga binaan di lapas, pemberian remisi seperti itu menguntungkan Negara dan juga Masyarakat tentunya, siapa yang membayar untuk membuat gedung lapas, siapa yang membayar petugas yang menjaga di lapas, dan siapa yang

9 Narapidana tindak pidana pencurian nama tidak disebutkan demi melindungi informan, (wawancara tanggal 28 April 2015) membayar makanan apa yang mereka makan di lapas, itu semuanya menggunakan uang dari rakyat, jadi rakyat merasa untung jika mereka tidak terlalu lama didalam tahanan uang negara tidak terus - terusan untuk membiayai mereka untuk hidup di dalam lapas". ${ }^{10}$

Dari hasil wawancara di atas, bahwa Kadivpas Kanwil Kemenkumham sendiri mendukung pemberian remisi yang disesuaikan dengan syarat - syarat yang harus di laksanakan, ternyata tidak sejalan dengan apa yang menjadi tujuan Pidana, menurut Saharjo tujuan dari pidana penjara itu sendiri adalah sebagai berikut

a. Menimbulkan rasa derita pada terpidana karena dihilangkannya kemerdekaan bergerak.

b. Membimbing terpidana agar bertobat.

c. Mendidik supaya ia menjadi seorang anggota masyarakat sosialis di Indonesia yang berguna. ${ }^{11}$

Ditinjau dari aspek filosofis bahwasanya pemidanaan bagi pelaku

${ }^{10}$ Sunar Agus,BC.Ip,S.H.,M.H, Kadivpas Kanwil Kemenkumham Bengkulu (wawancara tanggal 6 Mei 2015)

${ }^{11}$ DR. Hj. Tina Asmarawati, S.H., M.H, pidana dan pemidanaan dalam sistem hukum di Deepublish,2014),hlm.44 indonesia,(Sleman : 
kejahatan diberikan agar pelaku kejahatan jera atas perbuatan yang telah dilakukannya tetapi fakta di lembaga pemasyarakatan kelas II - A kota bengkulu malah memberikan ruang gerak kepada narapidana tindak pidana korupsi untuk bebas keluar dari kurungan, bebas melakukan apa yang mereka inginkan dan tidak adanya pendidikan integritas yang tinggi kepada narapidana untuk belajar supaya ia bisa menjadi seseorang yang sosialis bagi negara, berarti ini sama sekali tidak sesuai dengan tujuan pidana menurut saharjo, hal ini jelas hanya merupakan kepuasan dari penguasa, bilamana ia cenderung tidak memperdulikan kepentingan kepentingan rakyat yang memimpikan bahwa koruptor yang telah merugikan negara untuk dihukum seberat - beratnya dan tidak ada ampunan untuk para koruptor dan selain itu juga melihat aspek sosiologis, sejatinya masyarakat tidak menghendaki adanya pemberian remisi bagi terpidana korupsi karena korupsi merupakan musuh terbesar masyarakat Indonesia.

Didalam teori ini pembalasan bukanlah suatu metode yang digunakan di lembaga pemasyarakatan kelas II - A kota Bengkulu, melainkan reintegrasi sosial yang diterapkan. Banyak teori berkembang untuk menelaah mengapa seseorang melakukan kejahatan, sedangkan yang lainnya tidak melakukannya. Pada prinsipnya, kejahatan tersebut muncul dari dalam diri orang itu sendiri, baik secara fisik maupun secara psikis, atau kejahatan tersebut muncul dari luar orang tersebut, dalam hal ini kejahatan dianggap berasal dari pola perilaku masyarakat disekitar kehidupan orang tersebut, maupun karena sistem hukum yang melemahkan tujuan pemidanaan yang sejatinya tidak benar benar ingin membina.

Berikut bentuk - bentuk pembinaan yang ada di Lembaga Pemasyarakatan Kelas II - A Kota Bengkulu, sebagai berikut :

1. Pembinaan Rohani

Pembinaan Rohani Islam dilaksanakan secara rutin setiap hari dalam bentuk majelis ta'lim bekerjasama dengan Kantor Departemen Agama Kota Bengkulu, Pondok Pesantren, Institut Agama Islam Negeri (IAIN) dan Ormas-ormas Islam lainnya.

2. Pembinaan kesadaran berbangsa dan bernegara dalam bentuk Penyuluhan, Upacara Kesadaran Nasional setiap tanggal 17 Agustus serta tiap tanggal 
Tinjauan Yuridis Pemberian Remisi Kepada Narapidana Tindak Pidana Korupsi

Ditinjau dari Tujuan Pemidanaan

27 April untuk memperingati Hari Bhakti Pemasyarakatan.

3. Pembinaan kesehatan jasmani, hal ini dilakukan dengan cara olah raga rutin yang dilakukan pihak lapas kepada narapidana, olah raga ini seperti Futsal, dan lain sebagainya.

4. Pembinaan Keterampilan, seperti Pengrajin Batu akik, beternak lele, dan lain sebagainya.

Berdasarkan penelitian yang dilakukan penulis efektivitas dalam pembinaan, Lapas sendiri belum mampu membuat sistem yang baik sehingga dapat dikatakan bahwa sistem lapas tidak ideal dengan kesadaran para narapidana yang berada didalamnya untuk sadar. Artinya jelas disini bahwasanya penghukuman dalam pidana tersebut agar orang yang melakukan kejahatan tersebut sadar dan jerah atas perbuatan yang telah dilakukannya. Dan tidak ada jaminan bagi terpidana korupsi untuk sadar setelah diberikan remisi dan kecenderungan yang bisa timbul ialah perilaku yang sama dikemudian hari dan tidak jera sehingga mengubah paradigma sistem pemidanaan di Indonesia menjadi lemah.
Berdasarkan uraian dari bab sebelumnya penulis dapat menarik kesimpulan sebagai berikut :

1. Dari hasil penelitian di Lembaga Pemasyarakatan Kelas II - A Kota Bengkulu tujuan utama pemberian remisi adalah sebagai motivasi agar narapidana tindak pidana korupsi tidak lagi mengulangi perbuatannya tetapi remisi disini bukan untuk mendorong mereka untuk merubah akhlak mereka tetapi cenderung berpura - pura baik untuk cepat keluar dari lembaga pemasyarakatan.

2. Dalam hal ini jelas pemberian remisi sungguh tidak sesuai dengan semangat Pemerintah untuk memberantas tindak pidana korupsi dan tidak sesuai dengan tujuan dari pemidanaan karena dengan pemberian remisi justru tidak menimbulkan efek jera bagi pelaku tindak pidana korupsi dengan model pembinaan narapidana tindak pidana korupsi yang diperlakukan sama dengan narapidana umum lainnya, dengan hal seperti ini tujuan dari pembinaan agar narapidana jera dan merubah perilakunya tidak tercapai.

\section{Saran}

Berdasarkan uraian dari kesimpulan yang telah penulis paparkan diatas, maka 


\section{P-ISSN : 2599-1892}

Vol. 1, No. 1, Januari 2018

penulis memberikan sedikit sumbang fikir dalam bentuk saran kepada :

1. Pemerintah

a. Diharapkan pihak Kepala Lembaga Pemasyarakatan kelas II - A Kota Bengkulu sebagai Pimpinan lembaga Pemasyarakatan dapat mengusulkan pemberian remisi terhadap narapidana tindak pidana korupsi lebih mendahului yang benar - benar telah merubah perilakunya agar nantinya setelah keluar dari lembaga pemasyarakatan bisa berbaur dengan masyarakat luas dan berbuat kebaikan.

b. Diharapkan Kepala Lembaga Pemasyarakatan kelas II - A Kota Bengkulu yang dalam hal ini Pimpinan dari lembaga pemasyarakatan untuk dapat merubah model atau bentuk bentuk pembinaan narapidana tindak pidana korupsi agar tidak disamakan dengan narapidana umum lainnya, dengan diberikannya pendidikan tentang integritas sosial dan pembinaan yang sesuai agar mereka mengerti dan sadar akan perbuatan mereka dahulu sehingga tidak menutup kemungkinan narapidana tindak pidana korupsi yang sekarang masih berada di lembaga pemasyarakatan kelas II - A Kota Bengkulu setelah bebas tidak akan mengulangi perbuatannya, sehingga tujuan dari pembinaan dapat tercapai.

\section{DAFTAR PUSTAKA}

\section{Buku}

A. Hamzah, Pemberantasan Korupsi Melalui Hukum Pidana Nasional dan Internasional, Raja Grafindo Persada, Jakarta, 2005

Hermin Hadiati, Asas-asas Hukum Pidana. Ujung Pandang : Lembaga Percetakan dan Penerbitan Universitas Muslim Indonesia, 1995

Hilman Hadikusuma, Metode Penulisan Kertas Kerja dan Pembuatan Skripsi, Bandung, Rosda Karya; 1995

Ibnu Subiyanto, Metodologi Penelitian, Depok : Universitas Gunadarma,2010

Jan Remmelink, Hukum Pidana, Komentar atas Pasal-Pasal Terpenting dari KUHP Belanda dan Padanannya 
Tinjauan Yuridis Pemberian Remisi Kepada Narapidana Tindak Pidana Korupsi

Ditinjau dari Tujuan Pemidanaan

dalam KUHP Indonesia, Jakarta:

PT. Gramedia Pustaka Utama, 1993

Leden Marpaung, Asas-Teori-Praktik Hukum Pidana, Sinar Grafika,. Jakarta, 2005

M. Sholehuddin, Sistem Sanksi Dalama Hukum Pidana : Ide Dasar Double Track System dan Implementasinya, Jakarta:

Rajawali, 2004

Dr.Munir Fuady, Teori - teori Besar dalam Hukum.(Jakarta :kencana, 2013)

Muladi dan Barda Nawawi Arief, TeoriTeori Dan Kebijakan Pidana, Bandung: Alumni, 1984

P.A.F Lamintang, Hukum Penitensier Indonesia, Armico, Bandung, 1988

Philippe nonet dan philip selznick, Hukum responsif, Bandung : Nusamedia, 2007

Prof.Drs.C.S.T. Kansil,S.H., dan Christine ST. Kansil,SH,M.H., Pengantar Ilmu hukum Indonesia, Jakarta, PT. Rineka Cipta; 2011

Romli Atmasasmita, Kapita Selekta Hukum Pidana dan Kriminologi, Bandung : Mandar Maju, 1995
Van Bemmelen, Hukum Pidana 1, Cetakan Kedua, Bandung : Bina Cipta,1997

Wirjono Prodjodikoro, Hukum Acara Pidana di Indonesia, Sumur Bandung, Bandung, 1981

\section{Peraturan Perundang - undangan}

Al Quran dan Al Hadits.

Undang - undang Dasar Negara Republik Indonesia 1945.

Undang - undang No. 8 tahun 1981

tentang Kitab Undang - undang

Hukum acara Pidana.

Undang - undang No. 12 tahun 1995

tentang Pemasyarakatan

Undang - undang Republik Indonesia No.

31 tahun 1999 tentang

pemberantasan tindak pidana korupsi.

Peraturan Pemerintah No. 99 tahun 2012 tentang Perubahan kedua atas Peraturan Pemerintah No.32 tahun 1999 tentang syarat dan tata cara pelaksanaan hak warga binaan pemasyarakatan.

Undang - undang No.71 tahun 2001 tentang Tata Cara pelaksanaan peran serta masyarakat dan pemberian penghargaan dalam 
pencegahan dan pemberantasan

korupsi.

Undang - undang No.28 tahun 1999

tentang Penyelenggara Negara yang

bersih dan bebas dari Korupsi,

Kolusi dan Nepotisme.

\section{Artikel / Karya Ilmiah}

http://jhaywardana.blogspot.com

http://arwansaditama.blogspot.com/2009/

01/masa-depan-pergumulan-

pemikiran.html

http://bersukacitalah.wordpress.com/tag/t

ahap-tahap-analisis-kualitatif/

http://www.zonasiswa.com/2014/07/peng

ertian-hukum-lengkap.html 